\title{
Intervention of Sensitivity Training in Human Relationship Management in a Information Technology Organization
}

\author{
Ms. SEEMA KUMARI GUPTA \\ (Research Scholar - Bharathiar University)
}

\begin{abstract}
:
The paper is on intervention of sensitivity training in Human Relationship Management, this is a powerful interference on self-awareness which gives an insight into all aspects of an individual relationship in their personal life as well as professional life. It is an orientation towards group dynamics process by which organizations educate themselves in order to achieve better problemsolving capabilities through healthier human relationship management. This in turn a significant positive change is achieved in the working cordial human relation between members.

In this context, IT Organization (Confidential) categorical nominated their staff of various ranks for sensitivity training programme. The findings of 100 respondents are i) null hypothesis is accepted as $p$ is greater than 0.05 which means that there is no association between gender and interpersonal relationship during the sensitivity training. ii) a) If $p$ value $<0.05$, reject null hypothesis. The impact of Sensitivity program on conflict management varies at different age groups and b) If $p$ value $>0.05$, accept null hypothesis. The impact of Sensitivity program on conflict management is the same at different age groups.
\end{abstract}

Key Words: Sensitivity Training, Human relationship management, T-group, training evaluation

\subsection{INTRODUCTION}

The human resource department of The IT Company has been sending their employees to sensitivity training progarmme to Indian Society of Applied Behaviour Science (ISABS). A major contributing factor was that in the previous eight years, 500 of its 1528 employees had experienced a cutting edge T-group model. The present research paper exhibit how T-groups intervene in human relationship management (HRM) which have significant impact on business to maintain relationship within the group to reach their goals.

\subsection{SENSITIVITY TRAINING}

The ultimate goal of the training is to have intense experiences leading to life- changing insights, at least during the training itself and briefly afterwards. The highlights of this training programme are:

- The three important element of sensitivity training are here-and-now orientation, immediate feedback, and focus of group process. The ultimate aim is to learn to understand oneself and appreciate the differences in other people.

- The group dynamics processes whereby the Interaction leads to various interpersonal situations are as different ways of communicating, making decisions, handling conflicts in groups and obtaining co-operation. It also expects to expose the trainees and modify certain values held by typical executives; values which if not modified will impair interpersonal effectiveness. 
- The most important feature is that training is conducted in isolation away from their work situation. The experience starts with an unplanned agenda which creates a dilemma in the group, at times rules, norm and procedure are imposed causing conflicts leading to group dynamics, unfreezing of old values, learning new values and freezing the same.

- The training emphasizes on the fact that each of us have the ability to solve any type of problems that could bring out the confidence in the person.

- The participants also learn to tolerate ambiguity to see and examine their own behavior in the here \& now situation in an unstructured setting. Analyze the situation, understanding the processes and finding meaning to events happening in the laboratory are some of the ways in which T-groups help people learn how to learn and develop.

- It encourages team spirit as each member learns from the others and vice-versa. This helps everyone to appreciate the potential contributions of the other team members.

\subsubsection{Sensitivity Training from Human Relationship Management Point of View:}

Organizations comprise of people who interact and benefit from such training. The goals of an organization are related to increased production or higher profits margins. Sensitivity training heightens the awareness of hidden, but complex barriers that could have an influence on job performance, productivity, safety, employee retention, health, and quality customer service.

It is an orientation towards group dynamics as it is one of Organizational development (OD) intervention process by which organizations educate themselves in order to achieve better problemsolving capabilities. OD places more of its focus on becoming aware of one's role within work-place dynamics, leading to more effective group functioning as one of the traits of sensitivity training.

\subsection{Company Profile:}

The IT Company is a global IT solutions \& services company with its Head Quarters in Mumbai. The IT Company is ranked number 6 in India IT companies in 2013-2014. The company has 39 registered offices in 23 countries. It employs standards of the Software Engineering Institute's (SEI) Capability Maturity Model Integration (CMMI) and is a Maturity Level 5 assessed organization.

\subsection{DESIGN OF THE RESEARCH:}

\subsubsection{Objective of the study:}

a) To ascertain from the participants gender and interpersonal relationship

b) To seek relationship between age and conflict management after the sensitivity training program

\subsubsection{Hypothesis}

Hypothesis I: To find out whether there is association between gender and interpersonal relationship after the sensitivity training 
Hypothesis II: There is significant difference between significant difference between age and conflict management after sensitivity training program

\subsubsection{Methodology:}

A Questionnaire was designed and it was pre-tested on a sample of ten executive who had attended the program. Based on the feedback the questionnaire was modified and a final version was frozen. Sample of 100 respondents were selected through a random sampling process among the participants who attended this programme during 2015 from IT Company.

\subsubsection{Research Tool}

The software used to analyze the results by the researcher was SPSS 22. The statistical tools applied was

a) Chi square Test for association of two attributes: The Chi-Squared Test of Association allows the comparison of two attributes (i.e. Qualitative variables) in a sample of data to determine if there is any relationship between them. The idea behind this test is to compare the observed frequencies with the frequencies that would be expected if the null hypothesis of no association / statistical independence were true. By assuming the variables are independent, we can also predict an expected frequency for each cell in the contingency table. If the value of the test statistic for the chi-squared test of association is too large, it indicates a poor agreement between the observed and expected frequencies and the null hypothesis of independence / no association is rejected.

c) One way ANOVA: The test is used to decide whether the difference between more than two averages of independent populations is statistically significant using sample averages.

\subsubsection{Data Collection:}

The questionnaire was emailed to 120 participants of 100 responded and the remaining 20 responses either the data were incomplete or insufficient. The confidentiality of the responses was ensured by not asking them to disclose their names.

\subsection{ANALYSIS AND INTERPRETATION}

\subsubsection{Percentage Analysis}

Employees working in IT Company in Chennai were selected for the study. Personal and professional profile of the employees has studied in terms of age, marital status and education Table 1.1 displays the personal and professional details of the respondents.

\section{Chart 1.1 Frequency and Percentage Distribution of Demographic Characteristics}




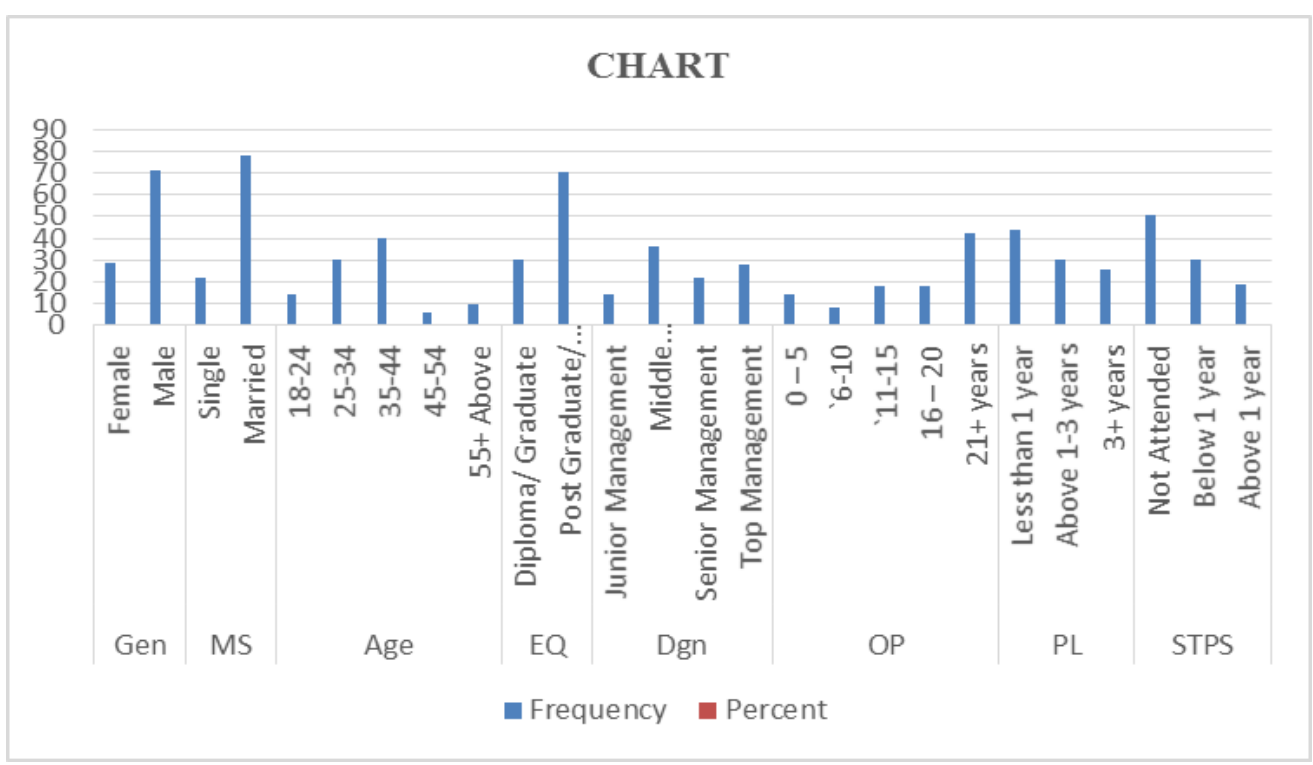

Where Gen: Gender; MS:Marital Status; EQ: Educational Qualification; Dgn: Designation; OP: Overall Professional; Pl: Promoted lastly; STPS: Sensitivity Training Programme Status

\subsubsection{HYPOTHESIS}

$\mathrm{H}_{0}$ 1. Null hypothesis: There is no association between Gender and Interpersonal relationship during the sensitivity training

Table 1.1 Chi Square test to Test the Relationship between Gender and IPR

\begin{tabular}{|l|c|c|}
\hline & \multicolumn{2}{c|}{ Gender } \\
\hline \multicolumn{1}{|c|}{ Interpersonal Relationship (IPR) After the Sensitivity Programme } & Chi & P \\
& Value & Value \\
\hline I feel that I am the one to blame for it & $6.752^{\mathrm{a}}$ & 0.564 \\
\hline I feel that I am the one who is responsible for what has happened & $7.787^{\mathrm{a}}$ & 0.455 \\
\hline I think about the mistakes I have made in this matter & $9.216^{\mathrm{a}}$ & 0.162 \\
\hline I think that basically the cause must lie within myself & $13.180^{\mathrm{a}}$ & 0.04 \\
\hline I think that I have to accept that this has happened & $5.758^{\mathrm{a}}$ & 0.451 \\
\hline I think that I have to accept the situation & $11.341^{\mathrm{a}}$ & 0.023 \\
\hline I think that I cannot change anything about it & $3.594^{\mathrm{a}}$ & 0.464 \\
\hline I think that I must learn to live with it & $5.372^{\mathrm{a}}$ & 0.497 \\
\hline I often think about how I feel about what I have experienced & $8.902^{\mathrm{a}}$ & 0.179 \\
\hline I am preoccupied with what I think and feel about what I have experienced & $1.175^{\mathrm{a}}$ & 0.556 \\
\hline I dwell upon the feelings the situation has evoked in me & $1.273^{\mathrm{a}}$ & 0.529 \\
\hline I think of nicer things than what I have experienced & $2.923^{\mathrm{a}}$ & 0.571 \\
\hline I think of pleasant things that have nothing to do with it & $.631^{\mathrm{a}}$ & 0.729 \\
\hline I think of something nice instead of what has happened & $2.943^{\mathrm{a}}$ & 0.567 \\
\hline I think about pleasant experiences & $11.402^{\mathrm{a}}$ & 0.077 \\
\hline I think of what I can do best & $5.416^{\mathrm{a}}$ & 0.492 \\
\hline I think about how I can best cope with the situation & $3.446^{\mathrm{a}}$ & 0.751 \\
\hline I think about how to change the situation & $5.475^{\mathrm{a}}$ & 0.484 \\
\hline I think about a plan of what I can do best & $8.294^{\mathrm{a}}$ & 0.405 \\
\hline I think I can learn something from the situation & $9.270^{\mathrm{a}}$ & 0.32 \\
\hline
\end{tabular}




\begin{tabular}{|l|c|c|}
\hline I think that I can become a stronger person as a result of what has happened & $10.112^{\mathrm{a}}$ & 0.257 \\
\hline I think that the situation also has its positive sides & $6.159^{\mathrm{a}}$ & 0.629 \\
\hline I look for the positive sides to the matter & 1.322 & 0.995 \\
\hline I think that it all could have been much worse & $3.676 \mathrm{a}$ & 0.885 \\
\hline I think that other people go through much worse experiences & $7.351 \mathrm{a}$ & 0.499 \\
\hline I think that it hasn't been too bad compared to other things & $3.342 \mathrm{a}$ & 0.911 \\
\hline I tell myself that there are worse things in life & $9.004 \mathrm{a}$ & 0.173 \\
\hline $\begin{array}{l}\text { I often think that what I have experienced is much worse than what others have } \\
\text { experienced }\end{array}$ & $7.378 \mathrm{a}$ & 0.287 \\
\hline I keep thinking about how terrible it is what I have experienced & $29.154 \mathrm{a}$ & 0.0000 \\
\hline $\begin{array}{l}\text { I often think that what I have experienced is the worst that can happen to a } \\
\text { person }\end{array}$ & $16.835 \mathrm{a}$ & 0.032 \\
\hline I continually think how horrible the situation has been & $3.728 \mathrm{a}$ & 0.000 \\
\hline I feel that others are to blame for it & $4.889^{\mathrm{a}}$ & 0.713 \\
\hline I feel that others are responsible for what has happened & $11.491^{\mathrm{a}}$ & 0.558 \\
\hline I think about the mistakes others have made in this matter & $8.294^{\mathrm{a}}$ & 0.175 \\
\hline I feel that basically the cause lies with others & $9.090 \mathrm{a}$ & 0.405 \\
\hline
\end{tabular}

The null hypothesis is accepted as $\mathrm{p}$ is greater than 0.05 which means that there is no association between gender and interpersonal relationship during the sensitivity training. Except for 'I keep thinking about how terrible it is what I have experienced' and 'I continually think how horrible the situation has been', there is association between gender and interpersonal relationship.

$\mathrm{H}_{0} 2$ Null Hypothesis: There is no significant difference between age and conflict management after sensitivity training program

Table 1.2: One Way ANOVA Conflict Management

\begin{tabular}{|c|c|c|c|c|c|c|}
\hline & & $\begin{array}{l}\text { Sum of } \\
\text { Squares }\end{array}$ & $\mathrm{df}$ & $\begin{array}{l}\text { Mean } \\
\text { Square }\end{array}$ & $\mathrm{F}$ & Sig. \\
\hline \multirow{3}{*}{$\begin{array}{l}\text { When conflict arises I propose } \\
\text { middle ground }\end{array}$} & Between Groups & 6.694 & 1 & 6.694 & \multirow[t]{3}{*}{5.168} & \multirow[t]{3}{*}{.025} \\
\hline & Within Groups & 126.946 & 98 & 1.295 & & \\
\hline & Total & 133.640 & 99 & & & \\
\hline \multirow{3}{*}{$\begin{array}{l}\text { I'm less comfortable interacting } \\
\text { with the opposite gender }\end{array}$} & Between Groups & .375 & 1 & .375 & \multirow[t]{3}{*}{.958} & \multirow[t]{3}{*}{.330} \\
\hline & Within Groups & 38.385 & 98 & .392 & & \\
\hline & Total & 38.760 & 99 & & & \\
\hline \multirow{3}{*}{$\begin{array}{l}\text { I'm tolerant of my own flaws and } \\
\text { inadequacies }\end{array}$} & Between Groups & 5.436 & 1 & 5.436 & \multirow[t]{3}{*}{7.346} & \multirow[t]{3}{*}{.008} \\
\hline & Within Groups & 72.524 & 98 & .740 & & \\
\hline & Total & 77.960 & 99 & & & \\
\hline \multirow{3}{*}{$\begin{array}{l}\text { It was important to me that I stay } \\
\text { level-headed in all situations } \\
\text { Office politics does not affect me }\end{array}$} & Between Groups & .012 & 1 & .012 & \multirow[t]{3}{*}{.014} & \multirow[t]{3}{*}{.906} \\
\hline & Within Groups & 84.988 & 98 & .867 & & \\
\hline & Total & 85.000 & 99 & & & \\
\hline \multirow{3}{*}{$\begin{array}{l}\text { I need stress to stay motivated and } \\
\text { productive. }\end{array}$} & Between Groups & .098 & 1 & .098 & \multirow[t]{3}{*}{.066} & \multirow[t]{3}{*}{.798} \\
\hline & Within Groups & 145.862 & 98 & 1.488 & & \\
\hline & Total & 145.960 & 99 & & & \\
\hline \multirow{3}{*}{ I'm not Comfortable with ambiguity } & Between Groups & 2.504 & 1 & 2.504 & \multirow[t]{3}{*}{2.082} & \multirow[t]{3}{*}{.152} \\
\hline & Within Groups & 117.856 & 98 & 1.203 & & \\
\hline & Total & 120.360 & 99 & & & \\
\hline \multirow{3}{*}{$\begin{array}{l}\text { I can always see beyond immediate } \\
\text { pressures to the bigger picture, and } \\
\text { the longer term implications/ } \\
\text { potential of a situation }\end{array}$} & Between Groups & .016 & 1 & .016 & \multirow[t]{3}{*}{.011} & \multirow[t]{3}{*}{.918} \\
\hline & Within Groups & 149.944 & 98 & 1.530 & & \\
\hline & Total & 149.960 & 99 & & & \\
\hline
\end{tabular}




\begin{tabular}{|c|c|c|c|c|c|c|}
\hline $\begin{array}{l}\text { Once I adopt a position I defend it } \\
\text { strongly }\end{array}$ & $\begin{array}{c}\text { Between Groups } \\
\text { Within Groups } \\
\text { Total }\end{array}$ & $\begin{array}{c}.039 \\
104.961 \\
105.000\end{array}$ & $\begin{array}{c}1 \\
98 \\
99\end{array}$ & $\begin{array}{c}.039 \\
1.071\end{array}$ & .037 & .848 \\
\hline $\begin{array}{l}\text { I attempt to get all concerns and } \\
\text { issues immediately out in the open }\end{array}$ & $\begin{array}{c}\text { Between Groups } \\
\text { Within Groups } \\
\text { Total } \\
\end{array}$ & $\begin{array}{c}1.334 \\
59.306 \\
60.640 \\
\end{array}$ & $\begin{array}{c}1 \\
98 \\
99 \\
\end{array}$ & $\begin{array}{l}1.334 \\
.605\end{array}$ & 2.204 & .141 \\
\hline $\begin{array}{l}\text { I prefer not to argue but to look for } \\
\text { the best solution possible }\end{array}$ & $\begin{array}{c}\text { Between Groups } \\
\text { Within Groups } \\
\text { Total }\end{array}$ & $\begin{array}{c}.568 \\
85.392 \\
85.960\end{array}$ & $\begin{array}{c}1 \\
98 \\
99\end{array}$ & $\begin{array}{l}.568 \\
.871\end{array}$ & .652 & .421 \\
\hline $\begin{array}{l}\text { I try to find some compromise } \\
\text { situation. }\end{array}$ & $\begin{array}{c}\text { Between Groups } \\
\text { Within Groups } \\
\text { Total } \\
\end{array}$ & $\begin{array}{c}2.805 \\
61.195 \\
64.000\end{array}$ & $\begin{array}{c}1 \\
98 \\
99 \\
\end{array}$ & $\begin{array}{l}2.805 \\
.624\end{array}$ & 4.492 & .037 \\
\hline Office politics affect me & $\begin{array}{c}\text { Between Groups } \\
\text { Within Groups } \\
\text { Total }\end{array}$ & $\begin{array}{c}2.674 \\
39.286 \\
41.960 \\
\end{array}$ & $\begin{array}{c}1 \\
98 \\
99 \\
\end{array}$ & $\begin{array}{l}2.674 \\
.401\end{array}$ & 6.670 & .011 \\
\hline I'm Comfortable with ambiguity & $\begin{array}{c}\text { Between Groups } \\
\text { Within Groups } \\
\text { Total } \\
\end{array}$ & $\begin{array}{c}2.448 \\
42.552 \\
45.000 \\
\end{array}$ & $\begin{array}{c}1 \\
98 \\
99 \\
\end{array}$ & $\begin{array}{c}2.448 \\
.434\end{array}$ & 5.639 & .020 \\
\hline $\begin{array}{l}\text { when I cannot handle stress I'm } \\
\text { completely thrown off -balance }\end{array}$ & $\begin{array}{c}\text { Between Groups } \\
\text { Within Groups } \\
\text { Total }\end{array}$ & $\begin{array}{c}1.634 \\
66.366 \\
68.000 \\
\end{array}$ & $\begin{array}{c}1 \\
98 \\
99 \\
\end{array}$ & $\begin{array}{l}1.634 \\
.677\end{array}$ & 2.413 & .124 \\
\hline $\begin{array}{l}\text { I'm intolerant of my own flaws and } \\
\text { inadequacies }\end{array}$ & $\begin{array}{c}\text { Between Groups } \\
\text { Within Groups } \\
\text { Total }\end{array}$ & $\begin{array}{c}.467 \\
44.533 \\
45.000\end{array}$ & $\begin{array}{c}1 \\
98 \\
99\end{array}$ & $\begin{array}{l}.467 \\
.454\end{array}$ & 1.027 & .313 \\
\hline $\begin{array}{l}\text { When conflicts arise I try to win my } \\
\text { case }\end{array}$ & $\begin{array}{c}\text { Between Groups } \\
\text { Within Groups } \\
\text { Total }\end{array}$ & $\begin{array}{c}.414 \\
24.546 \\
24.960\end{array}$ & $\begin{array}{c}1 \\
98 \\
99\end{array}$ & $\begin{array}{l}.414 \\
.250\end{array}$ & 1.653 & .202 \\
\hline $\begin{array}{l}\text { I'm feel perfectly comfortable } \\
\text { interacting with opposite gender }\end{array}$ & $\begin{array}{c}\text { Between Groups } \\
\text { Within Groups } \\
\text { Total }\end{array}$ & $\begin{array}{c}.082 \\
28.918 \\
29.000\end{array}$ & $\begin{array}{c}1 \\
98 \\
99\end{array}$ & $\begin{array}{l}.082 \\
.295\end{array}$ & .278 & .599 \\
\hline
\end{tabular}

If $\mathrm{p}$ value $<0.05$, reject null hypothesis

Interpretation: The impact of Sensitivity program on conflict management varies at different age groups

If $\mathrm{p}$ value $>0.05$, accept null hypothesis

Interpretation: The impact of Sensitivity program on conflict management is the same at different age groups

\subsection{RECOMMENDATIONS:}

The following are the suggestions by the respondents on strengthening the learning's received from this programme. The details are as follows:

\section{a. Criteria for Nomination:}

- To all people, irrespective of cadre, age \& function. This kind of exposure is more beneficial to young IT engineers.

- Pre- check the mental stability of the nominees before sending them for such a psychologically stressful programme.

\section{b. Sustainability of Learning's:}

- Reflection and internalization of the learning leads to change in the attitude. 
- The method of orientation could be more of pro-participant.

- All people should be involved to make it more effective. The training program is good but is not fully applied in reality since society, friends, seniors are involved.

- It is the individual who has to do it and not anybody else. Every individual has to sustain and improve. Others can do very little to help us.

- More efforts at personal level to understand self and the people around me. Conceptual knowledge to understand the human processes.

- Continue interactions with the participants. Utilize opportunities in interactions and discussions for analyzing how the individual and group dynamics work.

- A "mentor" in IT Company could help in sorting out few things so that continual improvement happens.

- In continuation to this workshop, a similar workshop in the campus of IT Company with at least two or three time for same staff to sustain the learning.

- To make the total process more effective the suggestions are as follows:

- Total change of culture of the organization.

- Judging the feeling and emotions of individual on the merit of expression rather the merit of the individual.

- Everybody's feelings and emotions should be given importance.

\section{c. Researcher's Recommendations to the Organization for sustaining the learning:}

- Create a forum for regular periodic meetings amongst participants, identify an accredited person as a mentor to the group.

- Unwinding and debriefing appropriately on return from the programme.

- Continuing to nominate so that more number of people are exposed.

- By seeking feedback from "significant others' of participants both at office and at home; a longitudinal research could be carried out to study whether behavioral modification has occurred.

\subsection{CONCLUSION:}

- This training had a positive impact on the behavior of participants both in their professional life and also in their personal life.

- Training lead to a significant positive change in the working relation between members which leads to better productivity, cordial working relationship and this would lead to fulfillment of organizational goals.

- The challenge for the trainee was to change his/her behavior and transfer the Learning's to work place/ Personal life. The myth that old habit seldom die. Here in this study the above myth has proved wrong. Change can happen at any age provide that if he/she is aware of their behavior and wants to change voluntarily. 


\section{REFERENCE:}

\section{Website Visited}

1. http://en.wikipedia.org/wiki/Organization

2. http://www.referenceforbusiness.com/management/Sc-Str/Sensitivity- Training.html

3. http://www.businessdictionary.com/definition/sensitivity-training.html

\section{Books Reviewed:}

1. Back, Kurt W. Beyond Words: The Story of Sensitivity Training and the Encounter Movement. 2nd ed. New Brunswick, NJ: Transaction Books, 1987.

2. Golembiewski, Robert T., and Arthur Blumberg, eds. Sensitivity Training and the Laboratory Approach: Readings about Concepts and Applications. 2nd ed. Itasca, IL: F.E. Peacock Publishers, Inc., 1973.

3. Green, Thad B., and Raymond T. Butkus. Motivation, Beliefs and Organizational Transformation. Westport, CT: Quorum Books, 1999.

4. Hornestay, David. "Sensitivity Training Can Strike A Nerve." Government Executive 33, no. 2 (February 2001): 73.

5. Lakin, Martin. Interpersonal Encounter: Theory and Practice in Sensitivity Training. New York: McGraw-Hill Book Co., 1972.

6. "Sensitivity Training." In Encyclopedia of World Problems and Human Potential. Brussels: Union of International Associations, 1994. 